\title{
Study on $\mathrm{HCl}$ system wet-etching process of GaSb-based materials
}

\author{
Minghui You ${ }^{1}$, Qixiang Sun ${ }^{1}$, Shijun $\mathrm{Li}^{1}$, Liping Yin ${ }^{1}$, Xue $\mathrm{Li}^{1}$, Jingsheng $\mathrm{Liu}^{1, \mathrm{a}}$ \\ ${ }^{1}$ Jilin Agricultural University, Changchun 130118, Jilin, China \\ amhyou000@163.com
}

Keywords: GaSb-based material; $\mathrm{HCl}$ system; wet-etching.

\begin{abstract}
In this paper, GaSb-based material in the near-infrared semiconductor laser has a broad application prospects. For the problems and etching solution suitable particularly critical of etching GaSb-based material. we studied on different etchant experimental analysis the $\mathrm{HCl}+\mathrm{HNO}_{3}(30+1) @ \mathrm{~T}=5 \quad{ }^{\circ} \mathrm{C} \quad, \quad 37 \% \quad \mathrm{HCl}, \quad \mathrm{HNO}_{3}+\left(0.08 \mathrm{MHCl}+\mathrm{CH}_{3} \mathrm{COOH}\right) \quad$ and $\mathrm{HCl}+\mathrm{H}_{2} \mathrm{O}_{2}+\mathrm{H}_{2} \mathrm{O}(60+1+1)$, due to etching, the effects of different etching solutions on GaSb surface morphology, corrosion rate, etc., obtained $\mathrm{HCl}+\mathrm{H}_{2} \mathrm{O}_{2}+\mathrm{H}_{2} \mathrm{O}(60+1+1)$ treatment results was better, SEM showed the etched edge relatively tidy, relatively steep side, etched crystal to better selectivity, AFM surface roughness was $1.7 \mathrm{~nm}$.
\end{abstract}

\section{Introduction}

The mid-infrared spectral region is of enormous interest as the practical realisation of optoelectronic devices operating in the $2-10 \mu \mathrm{m}$ wavelength range offers potential applications in a wide variety of areas including; optical gas sensing and environmental monitoring, free-space optical communications, infrared countermeasures, clean energy generation, biomedical and thermal imaging. For example, the mid-infrared contains the fundamental fingerprint absorption bands of a number of pollutant and toxic gases and liquids; methane $(3.3 \mu \mathrm{m}), \mathrm{CO} 2(4.6 \mu \mathrm{m})$, $\mathrm{CO}(4.2 \mu \mathrm{m}), \mathrm{NOx}(6.5 \mu \mathrm{m})$ and $\mathrm{SOx}(7.3 \mu \mathrm{m})$ require accurate, in situ multi-component monitoring in a variety of different situations (e.g. oil-rigs, coal mines, landfill sites,car exhausts) and in concentrations, ranging from $\mathrm{ppb}$ to almost $100 \%$.The mid-infrared is very attractive for the development of sensitive optical sensor instrumentation. [1-6] Not all compositions of InGaAsSb/AlGaAsSb type heterostructure are easily grown,there is a large miscibility gap,and serious carrier absorbtion. That significant affects the performance and application of multiple quantum-wells (MQWs) InGaAsSb/AlGaAsSb laser diodes.

GaSb-based materials in this band has unparalleled advantages, not only GaAs, InP-based materials compared to the process of antimony has its own characteristics and difficulties, but also especially in corrosion and other technology is still immature, making the device performance To a certain extent by the level of technology constraints [6-9], it is necessary to antimony lasers, detectors in-depth study of the device technology for the preparation of a good performance of the device to lay the foundation[7-9].

GaSb-based material etching and GaAs, InP similar to the main dry etching and wet etching. The GaSb-based etch is uniform and reproducible, but the selectivity is poor, so the underlying material is susceptible to damage. And the apparatus for dry etching is expensive, and the etching gas is poisonous, and there is a great danger. The experimental results show that the wet etching has the advantages of easy operation and easy realization for GaSb-based materials [9]. Therefore, the etching of this experiment is mainly discussed wet etching, through the selection of different proportions of corrosion solution, the corrosion of the surface oxide and impurities, but also on the corrosion of the material itself. In this paper, the etching effect of HCl-based GaSb material is studied, and the experiment is discussed and discussed. $\mathrm{HCl}+\mathrm{H}_{2} \mathrm{O}_{2}+\mathrm{H}_{2} \mathrm{O}(60+1+1)$. The results of SEM show that the edge of the mesa is regular and the side is steeper, and the selectivity of etching is better. 


\section{Experiment}

In the experiment, four kinds of $\mathrm{HCl}$ solutions were used: $\mathrm{HCl}+\mathrm{HNO}_{3}(30+1) @ \mathrm{~T}=5{ }^{\circ} \mathrm{C}, 37 \%$ $\mathrm{HCl}, \mathrm{HNO}_{3}+\left(0.08 \mathrm{M} \mathrm{HCl}+\mathrm{CH}_{3} \mathrm{COOH}\right)$ and $\left.\mathrm{HCl}+\mathrm{H}_{2} \mathrm{O}_{2}+\mathrm{H}_{2} \mathrm{O} 60+1+1\right)$. The etching rate of each etching solution was studied systematically, and the surface of the sample was observed by scanning electron microscope after etching.

\section{Results and Discussion}

The corrosion of antimony-containing compounds is generally divided into two steps: the initial oxidation process and the subsequent complexation process. The first solution to be solved is the dissolution of the surface of the antimony compound. In the case of conventional etching solutions, the presence of antimony (Sb) in the reaction with the GaSb-based material produces a poorly soluble oxide in the acid-base solution, limiting and hindering the further progress of the reaction, and the resulting product adheres to the surface, Affecting the precise control of etching. In the choice of solution can choose acidic etching solution can be dissolved antimony oxide complex. Although the tartaric acid ion in the etching solution and the Sb2O3 formed by the oxidation of $\mathrm{H}_{2} \mathrm{O}_{2}$ oxidizer are complexed to form a corrosion solution which can dissolve in the corrosive liquid, which is formed by the mixture of $\mathrm{HCI}, \mathrm{NaK}$ and $\mathrm{H}_{2} \mathrm{O}_{2},\left(\mathrm{C}_{6} \mathrm{H}_{4} \mathrm{O}_{6}\right),{ }^{5}$ the reaction can be continued, but when the concentration of tartaric acid and hydrogen peroxide is low, the reaction rate is mainly controlled by the concentration of hydrogen peroxide, once the hydrochloric acid concentration is too low can not completely dissolve the generated oxide , It will hinder the reaction to continue, it will produce such as lateral erosion is small, less reproducible, is not conducive to the preparation of the device adverse effects.

Several other HCl-based etchants have been studied in this paper. The corrosion effects of several $\mathrm{HCl}$-based etchants were compared. As shown in Fig. 1, SEM images of $\mathrm{HCl}+\mathrm{H}_{2} \mathrm{O}_{2}+$ $\mathrm{H}_{2} \mathrm{O}(60+1+1)$ corrosive solution for $120 \mathrm{~s}$ are shown in Fig. 1 . The etched mesa edge is neat and the side is steeper. The selectivity is better, and the etching rate is $4 \times 10^{3} \mathrm{~nm} / \mathrm{min}$.

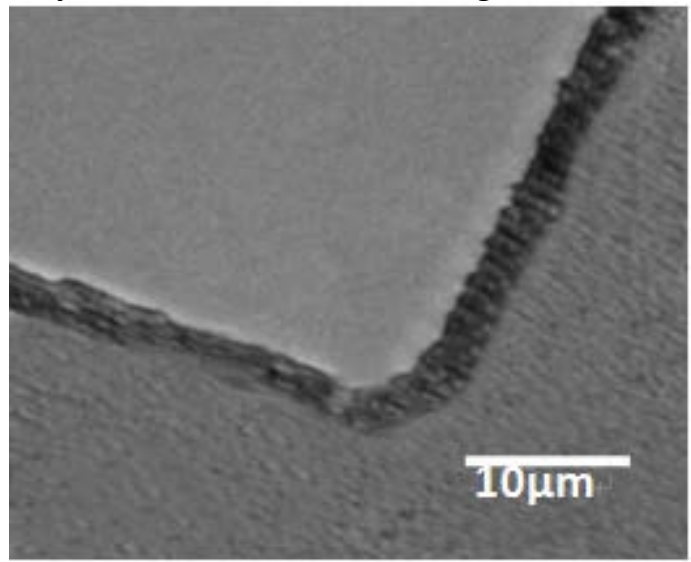

Fig. 1 The SEM image by $\mathrm{HCl}+\mathrm{H}_{2} \mathrm{O}_{2}+\mathrm{H}_{2} \mathrm{O}(60+1+1)$ etched 120 s

By $\mathrm{HCl}$ etchant, the concentration of $\mathrm{H}_{2} \mathrm{O}_{2}$ on the etching effect and corrosion rate is also very critical. $\mathrm{HCl}$ itself is less viscous, more easily diffused, the etch rate initially mainly by the $\mathrm{HCl}$ concentration and $\mathrm{H}_{2} \mathrm{O}_{2}$ concentration to performance. $\mathrm{HCl}$ concentration is too large, $\mathrm{HCl}$ and $\mathrm{H}_{2} \mathrm{O}_{2}$ diffusion increased, the etching rate is high. $\mathrm{HCl}$ concentration and $\mathrm{H}_{2} \mathrm{O}_{2}$ concentration ratio can be adjusted to change the corrosion effect. Moreover, as the temperature increases, the corrosion rate slows down, because the high temperature seriously affects the oxidation reaction, mainly $\mathrm{H}_{2} \mathrm{O}_{2}$ decomposition speeding up, excessive consumption of oxidants caused. It is expected that if the temperature continues to rise $\left(60^{\circ} \mathrm{C}\right)$, the corrosion rate will be greatly reduced.

The etching rate of several etching solutions such as $\mathrm{HCl}+\mathrm{HNO}_{3}(30+1) @ \mathrm{~T}=5{ }^{\circ} \mathrm{C}, 37 \%$ $\mathrm{HCl}$, and $\mathrm{HNO}_{3}+\left(0.08 \mathrm{M} \mathrm{HCl}+\mathrm{CH}_{3} \mathrm{COOH}\right)$ was investigated systematically. After etching, Surface of the initial determination of the sample surface quality, as shown in Table 1 . It shows the dependence of the etching depth on the etch depth of $\mathrm{HCl}+\mathrm{HNO}_{3}(30+1) @ \mathrm{~T}=5{ }^{\circ} \mathrm{C}, 37 \% \mathrm{HCl}$, 
and $\mathrm{HCl}+\mathrm{H}_{2} \mathrm{O}_{2}+\mathrm{H}_{2} \mathrm{O}(60+1+1)$, and the interpolated graph is a SEM scan. The etching rate was obtained by testing the etched depth and etched surface of the cleaned sample with a step tester. The results of SEM showed that the corrosion rate of $\mathrm{HCl}+\mathrm{H}_{2} \mathrm{O}_{2}+\mathrm{H}_{2} \mathrm{O}(60+1+1) \mathrm{GaSb}$ surface is smooth.

Tab.1 The surface conditions $4 \mathrm{HCl}$ systems etched with different etching rate

\begin{tabular}{lccc}
\hline \multicolumn{1}{c}{ Type } & Composition & $\begin{array}{c}\text { Ratio } \\
(\mathrm{nm} / \mathrm{min})\end{array}$ & Surface \\
\hline $\mathrm{HCl}$ & $37 \%$ & 40 & smooth \\
$\mathrm{HCl}+\mathrm{HNO}_{3}(30+1) @ \mathrm{~T}=5{ }^{\circ} \mathrm{C}$ & $30+1$ & 200 & mirror \\
$0.02 \mathrm{MBr}_{2}+0.02 \mathrm{M}$ & $1+1+(1+1)$ & 100 & smooth \\
$\mathrm{HNO}{ }_{3}+(0.08 \mathrm{M}$ & & & \\
$\left.\mathrm{HCl}+\mathrm{CH}_{3} \mathrm{COOH}\right)$ & $60+1+1$ & $4 \times 10^{3}$ & mirror \\
$\mathrm{HCl}+\mathrm{H}_{2} \mathrm{O}_{2}+\mathrm{H}_{2} \mathrm{O}(60+1+1)$ & & & \\
\hline
\end{tabular}

Fig. 2 is the AFM test after the corrosion surface morphology. The etching rate of $\mathrm{HCl}$ solution to $\mathrm{GaSb}$ solution is very slow $(\leq 50 \mathrm{~nm} / \mathrm{min})$, while $\mathrm{HCl}+\mathrm{H}_{2} \mathrm{O}$ and $\mathrm{HCl}+\mathrm{H}_{2} \mathrm{O}_{2}+\mathrm{H}_{2} \mathrm{O}(60+1+1)$ are more suitable for surface oxide removal. Reflected in the etching side of the smooth, cut under the effect of small. After etching about $1 \mu \mathrm{m}$, the surface roughness of $\mathrm{HCl}+\mathrm{H}_{2} \mathrm{O}$ is about $3 \mathrm{~nm}$ by AFM. However, the corrosion rate is too high, it is easy to cause surface quality deterioration. Overall, $\mathrm{HCl}+\mathrm{H}_{2} \mathrm{O}_{2}+\mathrm{H} 2 \mathrm{O}(60+1+1)$ treatment is better, the surface roughness of $1.7 \mathrm{~nm}$.
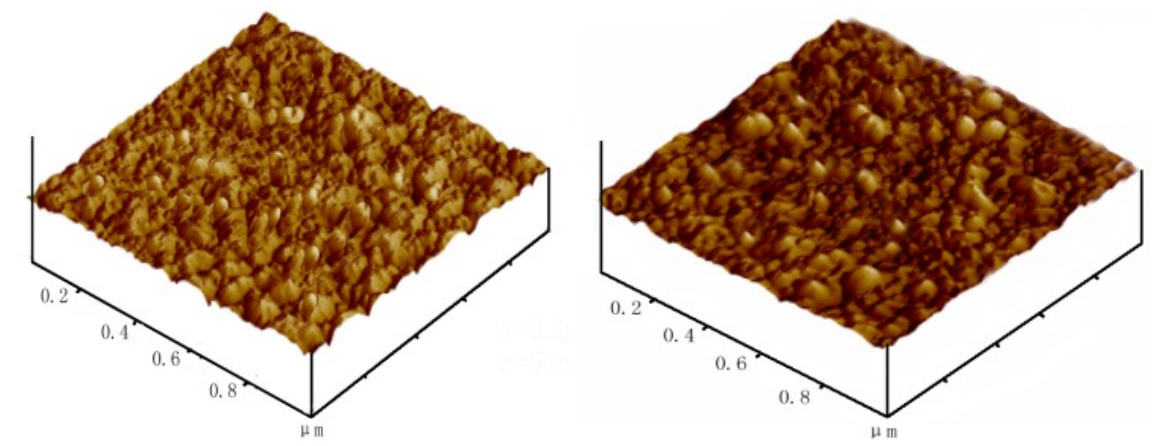

Fig.2 The AFM comparison chart etched with $\mathrm{HCl}+\mathrm{H}_{2} \mathrm{O}_{2}+\mathrm{H}_{2} \mathrm{O}(60+1+1)$ and $\mathrm{HCl}+\mathrm{H}_{2} \mathrm{O}$

\section{Conclusion}

In this paper, the corrosion behavior of $\mathrm{GaSb}$ on $\mathrm{HCl}+\mathrm{HNO}_{3}(30+1) @ \mathrm{~T}=5{ }^{\circ} \mathrm{C}, 37 \% \mathrm{HCl}$, $\mathrm{HNO}_{3}+\left(0.08 \mathrm{M} \mathrm{HCl}+\mathrm{CH}_{3} \mathrm{COOH}\right)$ and $\mathrm{HCl}+\mathrm{H}_{2} \mathrm{O}_{2}+\mathrm{H}_{2} \mathrm{O}(60+1+$ effect. The etching rate of each etching solution was studied in the experiment. The surface quality of the sample was determined by SEM and AFM after corrosion. The effects of different etching solutions on the surface morphology and corrosion rate of $\mathrm{GaSb}$ were studied. It was found that the surface of $\mathrm{GaSb}$ treated by $\mathrm{HCl}+\mathrm{H}_{2} \mathrm{O}_{2}+\mathrm{H}_{2} \mathrm{O}(60+1+1)$ was better than that of GaSb. SEM showed that the etched mesa edge was neat, The surface roughness of AFM was $1.7 \mathrm{~nm}$.

\section{Acknowledgments}

The authors wish to express their gratitude to the projects: Jilin Province Education Department Project (No. 2015Y174), Jilin Agricultural University learning program , Jilin Provincial Department of human resources and social security Project (No. 2015Y24)for their generous support of this work.

\section{References}

[1] C. Lin, Y. L. Zheng, Y. G. Zhang, et al, Temperature and injection current dependencies of $2 \mu \mathrm{m}$ InGaAsSb/AIGaAsSb quantum-well ridge-waveguide lasers, [J] J.Cryst. Growth (2007),225.

[2] Z.G.Li, G.J.Liu,M.H.You,et al, 2.0 $\mu \mathrm{m}$ Room Temperature CW Operation of 
InGaAsSb/AlGaAsSb Laser with Asymmetric Waveguide Structure, [J]Laser Physics, (2009)19, 1.

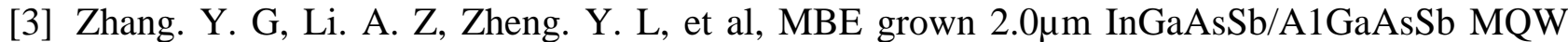
ridge waveguide laser diodes, [J] J.Crystal. Growth, （2001）,227: 582-585.

[4] K. Shim, H. Rabitz, P. Dutta: Band gap and lattice constant of $\mathrm{Ga}_{\mathrm{x}} \mathrm{In}_{1-\mathrm{x}} \mathrm{As}_{\mathrm{y}} \mathrm{Sb}_{1-\mathrm{y}}$. [J]J. Appl.Phys., (2000),88:7157.

[5] G.peake,R.shul,I.ashby,et al, Inductively coupled plasma reactive ion etching of GaInAsSb and $\mathrm{AlGaAsSb}$ for quanternary antimonide multiple interconnected module thermophotovoltaics, [J]J.Vacuum Sci. Tech.B, (2003),21,8:43.

[6] G.peake,R.shul,I.ashby,et al, Inductively coupled plasma reactive ion etching of GaInAsSb and $\mathrm{AlGaAsSb}$ for quanternary antimonide multiple interconnected module thermophotovoltaics, [J]J.Vacuum Sci. Tech.B, (2003),21,8:43.

[7] S. Corzine, R. Yan, L. Coldren: Optical gain in III-V bulk and quantum well semiconductors. In: P.S. Zory (ed.) Quantum well lasers. Academic Press, San Diego,(1986), 17-93.

[8] C. Alibert, A. Joullié, A.M. Joullié : Modulation-spectroscopy study of the Ga1-xAlxSb band structure. [J]Phys. Rev B (1983),27:4946.

[9] C. Mermelstein, S. Simanowski, M. Walther, et al.,Room-temperature low-threshold low-loss continuous-wave operation of $2.26 \mu \mathrm{m}$ GaInAsSb / AlGaAsSb quantum-well laser diodes. [J]Appl. Phys. Lett, (2000),77, 1581. 